\title{
Interaction of Lignans with Human Sex Hormone Binding Globulin (SHBG)
}

\author{
Matthias Schöttner ${ }^{\mathrm{a}}$, Dietmar Ganßer ${ }^{\mathrm{b}}$ and Gerhard Spiteller ${ }^{\mathrm{a}}$ \\ a Lehrstuhl Organische Chemie I, Universität Bayreuth, Universitätsstraße 30, \\ D-95440 Bayreuth, Germany \\ ${ }^{\mathrm{b}}$ Institut für Lebensmittelchemie, Universität Hannover, Wunstorfer Straße 14, \\ D-30453 Hannover, Germany
}

Z. Naturforsch. 52c, 834-843 (1997); received July 22/September 17, 1997

SHBG (SBP), Sex Hormone Binding Globulin, Synthesis of Lignans, Stobbe Condensation

Lignans bind to sex hormone-binding globulin (SHBG). The lignan with the highest binding affinity is ( \pm )-3,4-divanillyltetrahydrofuran. In a double Stobbe condensation - without use of protecting groups - a wide variety of lignans with different substitution pattern in the aromatic and aliphatic part of the molecule was synthesized. These lignans were tested in a SHBG-binding assay which allowed to deduce the following relationship between structure and activity: 1) ( \pm )-diastereoisomers are more active than meso compounds 2.) the 4-hydroxy-3-methoxy (guajacyl) substitution pattern in the aromatic part is most effective 3.) the activity increases with the decline in polarity of the aliphatic part of the molecule.

\section{Introduction}

Lignans, dimeric phenylpropanes, are typical plant constituents, are known to develop a great number of physiological activities (McRae and Towers, 1984; Nishibe 1993): Lignans have been recognized as platelet-activating factor antagonists (Coran et al., 1991), display digitoxin-like activities (Hirano et al., 1989) and show cytostatic effects especially on hormone dependent cancer cell lines (Hirano et al., 1990).

Some lignans are able to bind to human sex hormone binding-globulin (SHBG) (Martin et al., 1995; Ganßer and Spiteller, 1995), the major plasma sex steroid transport protein (Hammond and Bocchinfuso, 1995). The lignan with the highest present known affinity to SHBG is (-)-3,4-divanillyltetrahydrofuran (Schöttner et al., 1997).

The influence of structural modifications on their binding to SHBG has been investigated for steroids only. These studies indicated as prerequisite for highest binding affinities the presence of a $\pi$-donor as keto or hydroxy group in position 3 , a $\beta$-hydroxl group in position 17 and a planar conformation of the steroid (Cunningham et al., 1981). The influence of structural variation of lignans on their binding to SHBG is subject of this paper.

Reprint requests to Prof. Spiteller.

Fax: 0049-(0)-921-552671.
This investigation required the synthesis of lignans: A wide variety of compounds in substantial quantities for tests was needed. Since isolation of lignans from natural sources is time-consuming and provides the active compounds in poor yields only, the project required the use of a versatile synthesis. Several synthetic approaches have been published (Ward, 1982). In our laboratory the synthesis of lignans by a modification of the classical Stobbe route (Matsuura and Iinuma, 1984; Batterbee et al., 1969) in a variation of Daughan and Brown (Daughan and Brown, 1991) proved to be most suitable. This synthetic approach can be applied without use of protecting groups, and allows the preparation of a wide variety of lignans with different substitution pattern in the aliphatic and aromatic part of the molecules. Additionally the unsatured intermediates were suspected to show SHBG binding properties. Therefore they were also subjected to the test program. The wide variety of products available by the described synthetic approach allowed to perform a detailed study on structure-activity relationship of binding of lignans to SHBG.

\section{Results}

The synthetic approach

(E)-2-(4-Hydroxy-3-methoxy-benzyliden)dimethylsuccinate 1a was prepared by a Stobbe condensation of dimethylsuccinate and vanillin ac- 

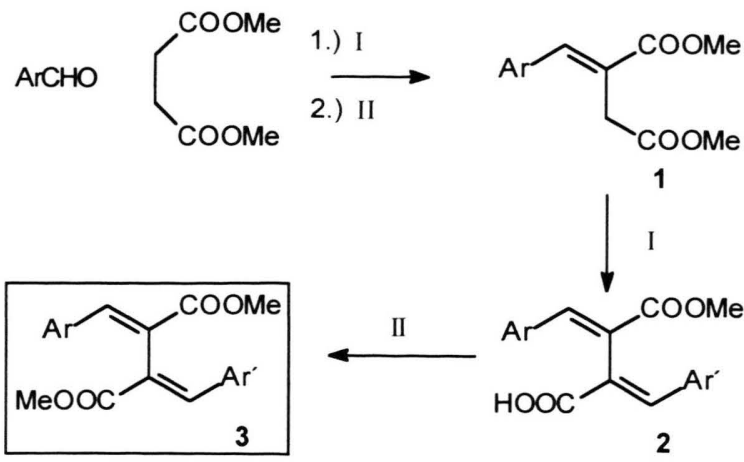

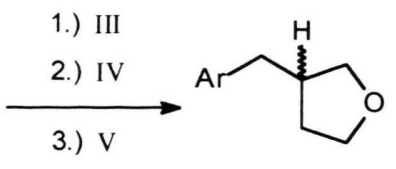

11

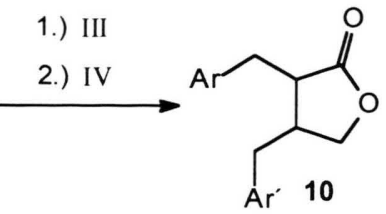

\section{VI}

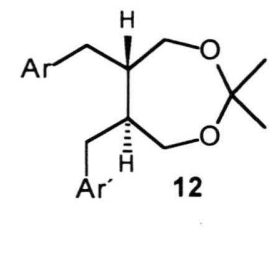

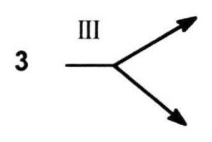
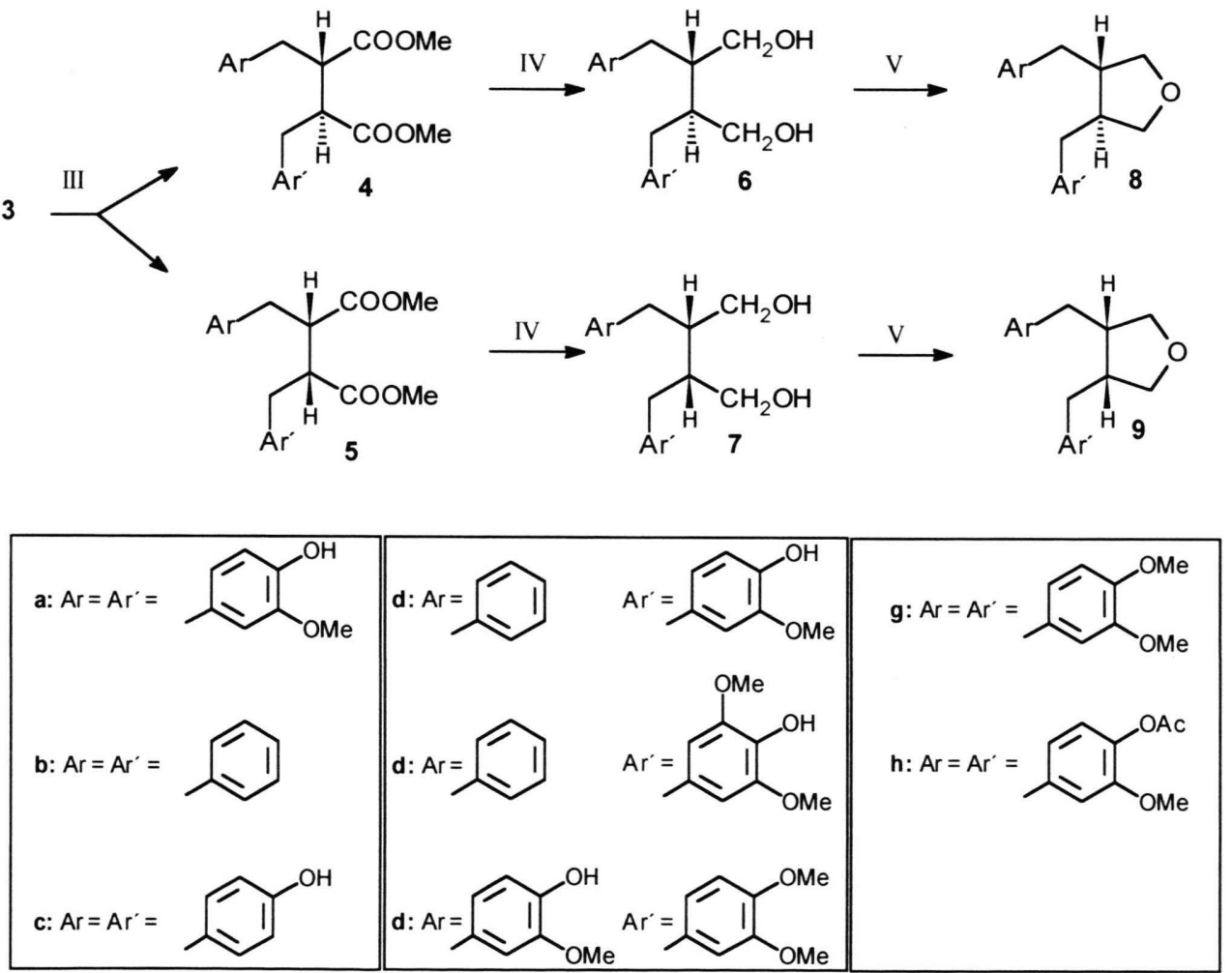

Scheme 1. Synthesis of several lignans. $\mathrm{I}=\mathrm{LiOMe} / \mathrm{MeOH}, \mathrm{II}=\mathrm{MeOH} / \mathrm{H}_{2} \mathrm{SO}_{4}, \mathrm{III}=\mathrm{Pd} / \mathrm{C} \mathrm{H} 2, \mathrm{IV}=\mathrm{THF} \mathrm{LiAlH}$, $\mathrm{V}=\mathrm{HC}(\mathrm{OMe})_{3} \mathrm{H}_{2} \mathrm{SO}_{4} \mathrm{MeOH}, \mathrm{VI}=\mathrm{HClO}_{4}$ acetone; (for enantiomeric pairs one enantiomer is shown only). 
cording to Daughan et al. (Daughan and Brown, 1991) followed by esterfication with methanol (Scheme 1). Repetition of this reaction sequence yielded the bisbenzylidenedimethylsuccinate $\mathbf{3 a}$. After hydrogenation the diastereoisomers $4 \mathbf{a}$ and 5a $(2: 1)$ were separated by recrystallisation from $\mathrm{MeOH} / \mathrm{THF}(1: 1 \mathrm{v} / \mathrm{v})$. The meso compound 5a crystallized much more readily than the isomeric compound $\mathbf{4 a}$, due to its poor solubility in organic solvents. Reduction of $\mathbf{4 a}$ and $\mathbf{5 a}$ with $\mathrm{LiAlH}_{4}$ yielded $( \pm)$-secoisolariciresinol $6 \mathbf{a}$ and meso-secoisolariciresinol 7a. ( \pm )-3,4-Divanillyltetrahydrofuran $8 \mathbf{a}$ was prepared by dehydration of $( \pm)$-secoisolariciresinol by use of acetone $/ \mathrm{HClO}_{4}$ as dehydration reagent (Cambie et al., 1985). The acetonide 12a was obtained as byproduct. It was separated by HPLC.

( \pm )-Secoisolariciresinol $6 \mathbf{a}$ and meso-secoisolariciresinol 7a were treated with $\mathrm{MeOH} /$ trimethylorthoformate to give ( \pm )-3,4-divanillyltetrahydrofuran and meso-3,4-divanillyltetrahydrofuran, respectively, in quantitative yield in a reaction not previously described. The reaction of $( \pm)$-3,4-divanillyltetrahydrofuran $8 \mathbf{a}$ with $\mathrm{CH}_{2} \mathrm{~N}_{2}$ yielded $\mathbf{8 f}$ and $( \pm$ )-brassilignan $\mathbf{8} \mathbf{g}$. The acetyl derivative $\mathbf{8 h}$ was obtained from $\mathbf{8 a}$ by treatment with AcOAc. Further variation of the aromatic substitution pattern of the lignans was achieved by using benzaldehyde, $p$-hydroxybenzaldehyde and syringaldehyde instead of vanillin.

\section{SHBG binding test}

The compounds obtained were subjected to an in-vitro assay described earlier (Ganßer and Spiteller, 1995). Briefly, different concentrations of a testsubstance were incubated with $\left[1,2-{ }^{3} \mathrm{H}(\mathrm{N})\right]$ dihydrotestosterone $\left({ }^{3} \mathrm{H}-\mathrm{DHT}\right) \quad\left[\begin{array}{ll}8.8 & \mathrm{~nm}\end{array}\right]$ and SHBG [9.7 nM]. SHBG is a homodimer where two molecules of SHBG are able to bind one molecule of ${ }^{3} \mathrm{H}$-DHT (Hammond and Bocchinfuso, 1995; Joseph, 1994). The chosen ${ }^{3} \mathrm{H}-\mathrm{DHT}$ concentration is able to saturate the protein $(4.8 \pm 0.3 \mathrm{~nm}$ bound). Nonbound ${ }^{3} \mathrm{H}$-DHT was separated by addition of dextran-coated charcoal. The remaining activity was corrected for the non-specific binding (0.04 nм ${ }^{3} \mathrm{H}$-DHT/nm protein) which was determined by use of a 300 -fold excess of non-labelled DHT instead of a test compound. Each point represents the mean of at least three measurements.

\section{Influence of variations in the aliphatic part of guajacyllignans on $\mathrm{SHBG}$ binding}

The influence of variations in the aliphatic part of lignans on the binding properties to SHBG was investigated with guajacyl lignans, since it was found that all guajacyllignans inhibited the binding of ${ }^{3} \mathrm{H}$-DHT to SHBG. Planarity is a prerequisite for an effective binding of steroids to SHBG (Cunningham et al., 1981). In contrast to this finding the unsaturated compounds 1a and 3a developed only a very low affinity to SHBG (Fig. 1). Hydrogenation of the double bonds of $\mathbf{3 a}$ results in an increase of the binding properties, whereby the $( \pm)$-diastereoisomer $\mathbf{4 a}$ turned out to be more effective than the meso compound 5a. This observation may be due to the low solubility of 5a observed in all organic solvents.

(-)-Matairesinol (-)-10a and $\mathbf{4 a}$ are of similar polarity, causing similar binding affinity to SHBG. An increase in polarity was achieved by the reduction of $4 \mathbf{a}$ to the natural product $( \pm)$-secoisolariciresinol 6a. This is reflected by a decrease in binding affinity to SHBG. Dehydration of the diols $\mathbf{6 a}$ and $7 \mathbf{a}$ produced the relatively nonpolar compounds 3,4-divanillyltetrahydrofuran $\mathbf{8 a}$ and $\mathbf{9 a}$. These compounds exhibited the highest affinity of all investigated lignan derivates. Comparison between $8 \mathbf{a}$ and $9 \mathbf{a}$ again revealed the superiority of

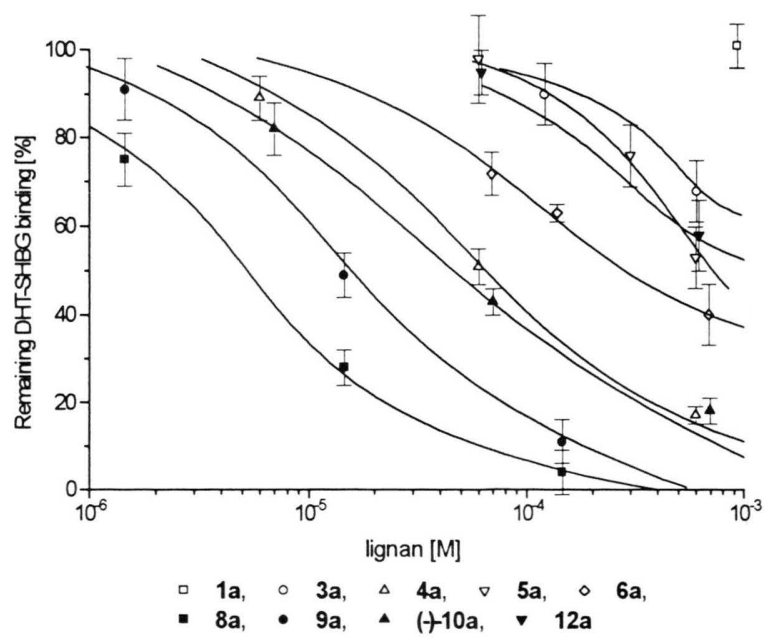

Fig. 1. Incubation of human SHBG, $\left[1,2-{ }^{3} \mathrm{H}(\mathrm{N})\right]$-dihydrotestosterone and synthetic lignans with variations in the aliphatic part of the molecule at different concentrations. 
the $( \pm)$-diastereoisomer over the meso compound with respect to their binding affinity.

\section{Influence of variations in the aromatic part of the lignans on $S H B G$ binding}

The influence of aromatic substitution pattern on the SHBG binding properties was tested by comparing compounds with an equivalent aliphatic part but different substitution pattern in the aromatic ring. The bisbenzyl dimethylsuccinates 4 and $\mathbf{5}$ with different aromatic substitution pattern are easily accessible synthetically by variation of the aldehydic compounds in the Stobbe condensation. Synthesis of $\mathbf{4 c}$ in the way described above failed due to the poor solubility of compound $\mathbf{3 c}$ in any organic solvent. Synthesis of the 10c was achieved by hydrogenation of $\mathbf{2 c}$ followed by reduction with $\mathrm{LiAlH}_{4}$. 10c was obtained as mixture of diastereoisomeric compounds in a ratio $2: 1$. The similar polarity of 10c compared to compounds of type $\mathbf{4}$ and $\mathbf{5}$ allowed comparison of their binding properties to SHBG.

According to the data given in Fig. 2 the diastereomers 4 always showed higher affinity to SHBG than the isomeric compounds $\mathbf{5}$. The affinity of the symmetrically substituted lignans decreased from 4a $>$ 4b $>10 c$.

Whether a symmetric aromatic substitution is required for an effective SHBG binding was clari-

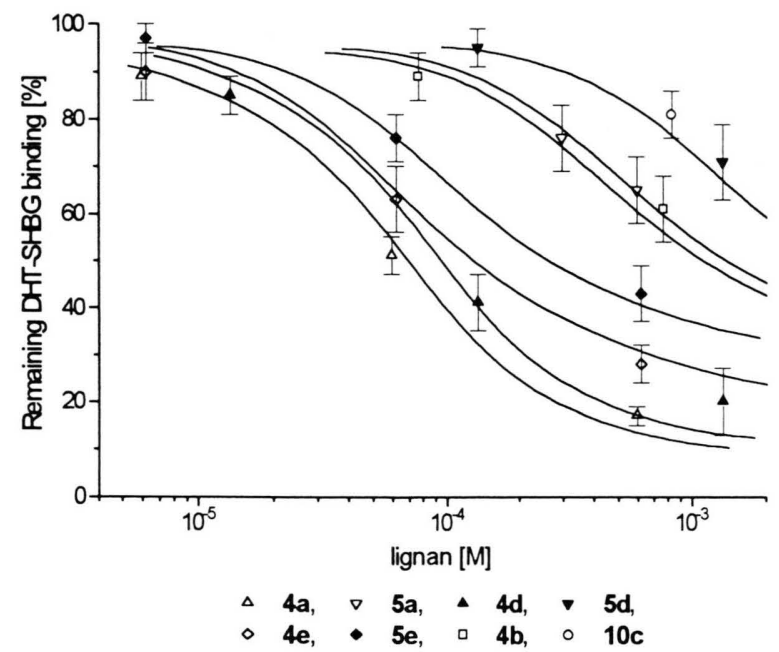

Fig. 2. Incubation of human SHBG, $\left[1,2-{ }^{3} \mathrm{H}(\mathrm{N})\right]$-dihydrotestosterone and lignans with various substituents in the aromatic part of the molecules in different concentrations. fied by coupling $\mathbf{1 b}$ as an aromatic group with low affinity with vanillin and syringaldehyde. After the usual reaction sequence the resulting diastereoisomers $\mathbf{4}$ and $\mathbf{5}$ were separated by HPLC. The compounds 4a, 4d and 4e exhibited comparable affinity to SHBG, whereby the affinity of $\mathbf{4 e}$ was found to be the lowest. Obviously binding to SHBG is strongly supported by the 4-hydroxy-3methoxy substitution pattern in one of the aromatic rings.

Further variation of the aromatic part of the molecule was achieved by derivatization of the highly active 8a with diazomethane. The mixture of methylation products was separated by HPLC providing the compounds $8 \mathbf{8}$ and $8 \mathbf{g}$. Treatment of $\mathbf{8 a}$ with pyridine and AcOAc yielded $\mathbf{8 h}$. Starting from compound 1a the tetrahydrofuran 11a was obtained by subsequent hydrogenation, reduction of the ester group and dehydration with trimethylorthoformate. The low affinity of 11a to SHBG (Fig. 3) proved the importance of a second aromatic residue for SHBG binding.

The extent of SHBG binding is reduced by any variation in the aromatic part of $\mathbf{8 a}$ as shown by the decline in affinity from $8 \mathbf{a}>\mathbf{8 f}>\mathbf{8} \mathbf{g}>\mathbf{8} \mathbf{g}$ to 8h (Fig. 3).

\section{Discussion}

Comparing all the tested compounds with respect to their binding affinity to SHBG, the $8-8^{\prime}$ coupled dimeric phenylpropane structure seems to

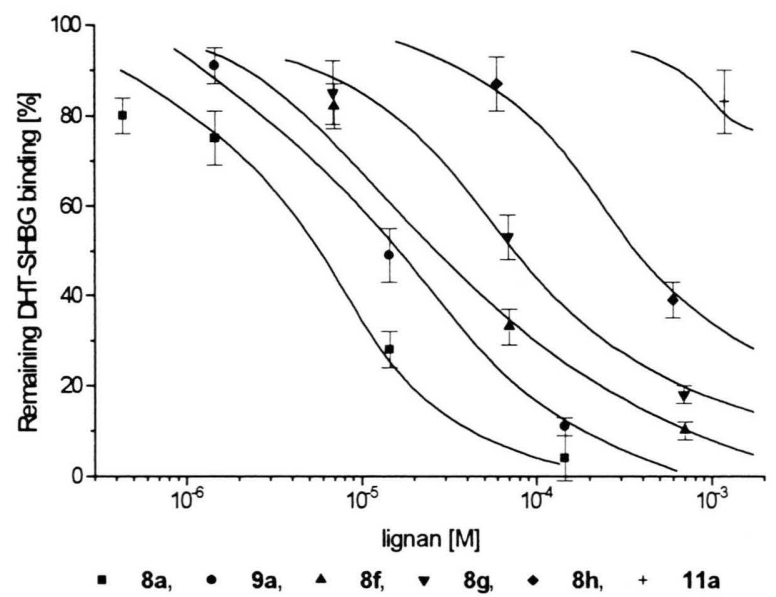

Fig. 3. Incubation of human SHBG, $\left[1,2-{ }^{3} \mathrm{H}(\mathrm{N})\right]$-dihydrotestosterone and different substituted monoepoxy lignans in different concentrations. 
be a prerequisite for an effective binding to SHBG. The loss of one benzylic part of the molecule causes a total loss in activity $(\mathbf{1 1 a}, \mathbf{1 a})$. The low activity of the unsatured compound $\mathbf{3 a}$ may be due to the low flexibility or for the wrong configuration of the double bond. It is apparent from the different guajacyl lignans $\mathbf{4 a}-\mathbf{1 0 a}$ that the affinity to SHBG can be correlated with the polarity of the substitutents at C-9 and C-9', resp.: The binding affinity increases with a decrease in polarity, starting from the diol $\mathbf{6 a}$ via the esters $4 \mathbf{a}$ and $\mathbf{1 0 a}$ to the tetrahydrofuran derivative $\mathbf{8 a}$. The acetalic compound 12a is exceptional. Its low affinity may be due to the bulky 7 -membered ring.

The ( \pm )-lignans $\mathbf{4}$ are always more effective than the analogous diastereoisomers 5. This tendency is also observed with the asymmetric lignans $\mathbf{4 d}$ and $4 \mathbf{e}$ which are superior to $\mathbf{5 d}$ and $\mathbf{5 e}$.

The most potent substitution pattern at the aromatic part of the molecule is the 4-hydroxy-3methoxyphenyl (guajacyl-) ring. This is in agreement with the high binding affinity of 2-methoxyestradiol to SHBG (Scheme 2) (Dunn et al., 1980), which is even more active than testosterone.

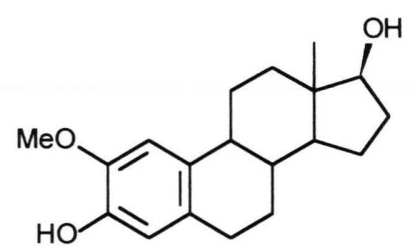

Scheme 2. Structure of 2-methoxyestradiol

Any variation of the aromatic substitution pattern leads to a decrease in activity. In asymmetrical lignans the aromatic part with the better binding properties is responsible for the binding affinity of the whole molecule. By comparing the achieved data the effectiveness of the substituted aromatic rings was estimated to be guajacyl > syringyl $\gg$ 3,4-dimethoxyphenyl $\sim$ phenyl $>$ 4-hydroxyphenyl $\sim$ 4-acetoxy-3-methoxyphenyl (Scheme 3).
The concentration of lignans in female urine was found to be dependent on the menstrual cycle (Setchell et al., 1980; Stitch et al., 1980). Therefore, lignans discovered in urine have been assumed to represent a new class of hormonal compounds (Setchell and Adlerkreutz 1988). The binding of lignans to SHBG emphasizes these hormone-like properties.

In man $58 \%$ of total testosterone is bound to SHBG (Vermeulen et al., 1971). The displacement of this sex hormone by lignans should cause a change in the concentration of free and therefore active steroid hormones (Mendel, 1989). SHBG is more than a simple transport protein. Beside the steroid hormone binding site SHBG has another binding site for specific receptors on the membranes of typical hormone target tissues (reviewed by Joseph, 1994). The receptor-SHBG interaction is effected by the occupancy of the steroid binding site (Hryb et al., 1990). Therefore an influence of lignans on this receptor SHBG interaction by lignans is conceivable.

The findings presented in this paper may contribute to develop a quantitative structure-activity relationship of lignans to SHBG which may allow the synthesis of even more active lignans in the future. Especially the remarkably high activity of ( \pm )-3,4-divanillyltetrahydrofuran suggests that this compound develops benefical properties in the treatment of hormone-dependent diseases (Pugeat et al., 1988), e.g. benign prostatic hyperplasia (Farnsworth, 1996).

Although lignans are present in higher concentrations than steroid hormones in blood plasma, (up to $1 \mu \mathrm{M}$, Adlercreutz, 1994), the pysiological relevance of their binding to SHBG is difficult to estimate and should be subject of further investigations.

\section{Experimental}

Melting points (m.p.): uncorr.; NMR: Bruker DRX 500, AM 300; EIMS: MAT 95 (Finnigan).<smiles>COc1cc(C)ccc1OCCCC(C)c1ccc(O)c(OC)c1O</smiles>

Scheme 3. Affinity to SHBG depending on the aromatic part of the molecules. 
GC $\left(\mathrm{H}_{2}\right.$ at $50 \mathrm{kPa}, 3 \mathrm{~min} 80^{\circ} \mathrm{C}, 80^{\circ} \mathrm{C}$ to $280^{\circ} \mathrm{C}$ with $3{ }^{\circ} \mathrm{C} \mathrm{min}{ }^{-1}, 280{ }^{\circ} \mathrm{C}$ for $15 \mathrm{~min}$ ) was performed on a Carlo Erba GC using a fused silica capillary column coated with DB 1 phase $(30 \mathrm{~m} \times 0.32 \mathrm{~mm}$, film $0.1 \mu \mathrm{m}, \mathrm{J} \& \mathrm{~W}$ Scientific). The retention index $\mathrm{R}_{\mathrm{i}}$ was calculated according to van den Dool et al. (Van den Dool and Kratz, 1963). HPLC: (Beckman) was used with a variable wavelength detector (detector 168) using $280 \mathrm{~nm}$ semiprep. HPLCcolumn Spherisorb ODS-2, $5 \mu \mathrm{m} \quad(240 \mathrm{~mm} \times$ $8 \mathrm{~mm}$ ). Trimethylsilylation was achieved by treatment with $N$-methyl- $N$-trimethylsilyltrifluoroacetamide (Macherey \& Nagel, Düren, Germany) for $8 \mathrm{~h}$ at room temperature. For synthesis only anhydrous solvents were used.

\section{(E)-2-(4-Hydroxy-3-methoxy-benzyliden)- dimethylsuccinate (1a)}

A Stobbe condensation of $21.45 \mathrm{~g}(0.14 \mathrm{~mol})$ vanillin and $18.38 \mathrm{ml}(0.14 \mathrm{~mol})$ dimethylsuccinate according to Daughan (Daugan and Brown, 1991) yielded $36.8 \mathrm{~g}$ crude halfester. The slightly yellow product was dissolved in $400 \mathrm{ml}$ dried $\mathrm{MeOH}$. Then a mixture of $100 \mathrm{ml}$ trimethylorthoformate, $2.5 \mathrm{ml} \mathrm{H}_{2} \mathrm{SO}_{4}(96 \%)$ and $100 \mathrm{ml}$ dried $\mathrm{MeOH}$ was added. After refluxing for $4 \mathrm{~h}$ a part of the solvent was removed to reach a volume of $200 \mathrm{ml}$. This solution was added to $500 \mathrm{ml}$ cooled $\left(0^{\circ} \mathrm{C}\right)$ halfsaturated $\mathrm{NaHCO}_{3}$ solution. The white precipitate was filtered and washed with water. After high vacuum drying $31.25 \mathrm{~g}$ crude diester was obtained. This product was recrystallized using $200 \mathrm{ml} \mathrm{di-}$ ethylether. Yield: $30.62 \mathrm{~g} \mathrm{(76 \% ).}$

$\mathrm{R}_{\mathrm{f}}(\mathrm{CH}-\mathrm{EtOAc} 2: 1)=0.57$; m.p. $($ EtOEt $)$ : $86^{\circ} \mathrm{C}$; RI (trimethylsilylated): 2200 ; MS $\mathrm{m} / z$ (rel. int): $280\left(\mathrm{M}^{+}, 100\right), 248$ (21), 220 (13), 189 (89), 161 (28), 145 (18); ${ }^{1} \mathrm{H}-\mathrm{NMR}\left(300 \mathrm{MHz}, \mathrm{CDCl}_{3}\right): \delta$ (ppm) 3.57 (s 2H H-8'), 3.70 (s 3H OMe); 3.78 (s $3 \mathrm{H} \mathrm{OMe);} 3.85$ (s $3 \mathrm{H} \mathrm{OMe}$ ); 5.87 (s $1 \mathrm{H} \mathrm{OH}$ ); $6.88-6.91$ (m 3H H-2/H-5/H-6).

\section{(E,E)-2,3-Bis-(4-hydroxy-3-methoxy-benzyliden)- monomethylsuccinate (2a)}

An analogous condensation of $14.26 \mathrm{~g}$ $(0.051 \mathrm{~mol}) \mathbf{1 a}$ and $7.75 \mathrm{~g}(0.051 \mathrm{~mol})$ vanillin yielded $17.81 \mathrm{~g}(87 \%)$ of the crude monoester $\mathbf{2 a}$.

$\mathrm{R}_{\mathrm{f}}(\mathrm{CH}-$ EtOAc $2: 1)=0,42$; RI (trimethylsilylated): 3095; MS (trimethylsilylated) $\mathrm{m} / z$ (rel. int.):
$616\left(\mathrm{M}^{+} 23\right), 601(9), 526(7), 499(6), 466(19), 437$ (11), 389 (12), 331 (17), 209 (82), 73 (100); ${ }^{1} \mathrm{H}-$ NMR (500 MHz, d d $_{4}$-methanol): $\delta(\mathrm{ppm}) 3.67$ (s $3 \mathrm{H} \mathrm{COOMe}$ ), 3.72 (s $3 \mathrm{H}$ ArOMe), 3.73 (s $3 \mathrm{H}$ ArOMe), $6.78\left(\mathrm{~d} 2 \mathrm{H}^{3} \mathrm{~J}=8.3 \mathrm{~Hz} \mathrm{H}-5 / 5^{\prime}\right), 7.11(\mathrm{~m}$ $\left.2 \mathrm{H} \mathrm{H}-6 / 6^{\prime}\right), 7.25$ (d $\left.1 \mathrm{H}^{4} J=2 \mathrm{~Hz} \mathrm{H}-2\right), 7.29$ (d $1 \mathrm{H}$ $\left.{ }^{4} J=2 \mathrm{H}-2^{\prime}\right), 7.82$ (s H-7); 7.84 (s H7').

\section{(E,E)-2,3-Bis-(4-hydroxy-3-methoxy-benzyliden)- dimethylsuccinate (3a)}

$17 \mathrm{~g}(0,045 \mathrm{~mol})$ crude monomethylester 2a were dissolved in $400 \mathrm{ml} \mathrm{MeOH}$. A mixture of $20 \mathrm{ml}$ trimethylorthoformate in $20 \mathrm{ml} \mathrm{MeOH}$ and $1 \mathrm{ml} \mathrm{H}_{2} \mathrm{SO}_{4}(96 \%)$ was added and refluxed for $27 \mathrm{~h}$. After cooling $1 \mathrm{~g} \mathrm{NaHCO}_{3}$ was added and the solvent reduced to $\sim 50 \mathrm{ml}$. After addition of $200 \mathrm{ml}$ half satured $\mathrm{NaHCO}_{3}$ the aqueous solution was extracted 3 times by $200 \mathrm{ml} \mathrm{CH}_{2} \mathrm{Cl}_{2}$. The organic phases were combined and dried over sodium sulfate. The solvent was removed, yielding $16.75 \mathrm{~g}$ crude product. After recrystallization from toluene $13.76 \mathrm{~g}(0.033 \mathrm{~mol}, 74 \%$ yield $)$ of the diester 3a were obtained.

$\mathrm{R}_{\mathrm{f}}(\mathrm{CH}-$ EtOAc $1: 1): 0.32$; m.p. $159-161^{\circ} \mathrm{C}$ (toluene); RI (trimethylsilylated): 3070; MS (trimethylsilylated) $\mathrm{m} / \mathrm{z}$ (rel. int.): $562\left(\mathbf{M}^{+}, 84\right), 547$ (5), 250 (7), 209 (100), 196 (18), 179 (17), 73 (21). ${ }^{1} \mathrm{H}-\mathrm{NMR}\left(500 \mathrm{MHz}, \mathrm{CDCl}_{3}\right): \delta 3.68 \quad(\mathrm{~s} \quad 6 \mathrm{H}$ COOMe), 3.69 (s 6H ArOMe), $6.73\left(2 \mathrm{H} \mathrm{d}^{3} \mathrm{~J}=8.3\right.$ $\mathrm{H}-5), 7.01$ (dd $\left.2 \mathrm{H}^{4} J=2.1 \mathrm{~Hz}{ }^{3} J=8.3 \mathrm{~Hz} \mathrm{H}-6\right)$, $7.16\left(\mathrm{~d} 2 \mathrm{H}{ }^{4} \mathrm{~J}=2.1 \mathrm{~Hz} \mathrm{H}-2\right), 7.84$ (s $\left.2 \mathrm{H} \mathrm{H}-7\right),{ }^{13} \mathrm{C}-$ $\left.\begin{array}{llllll} & \text { NMR } & (125 & \mathrm{MHz}\end{array}\right): \delta \quad 52.8 \quad$ (COOMe), 56.2 (ArOMe), 113.4 (C-2), 116.3 (C-5), 123.9 (C-8), 126.3 (C-6), 127.8 (C-1), 144.0 (C-7), 148.9 (C-3), 150.1 (C-4), 169.6 (C-9). The assignment of the carbons was achieved by HMQC (Heteronuclear Multiple Quantum Correlation) and HMBC (Heteronuclear Multiple Bond Correlation) experiments. The coupling constant of ${ }^{3} J_{\mathrm{C}-9 \mathrm{H}-7}=7.2 \mathrm{~Hz}$ proves the $(E, E)$-configuration of $\mathbf{3 a}$ (Kalinowski, 1987).

\section{2,3-Bis-(4-hydroxy-3-methoxy-benzyl)-dimethyl- succinate (4a, 5a)}

$2.02 \mathrm{~g}(4.88 \mathrm{mmol})$ of the diester 3a were stirred in $200 \mathrm{ml}$ methanol with $200 \mathrm{mg} \mathrm{Pd} / \mathrm{C}(5 \% \mathrm{Al}-$ drich) for 1 day under $200 \mathrm{kpa}$ hydrogen pressure. The solution was diluted with $200 \mathrm{ml}$ THF. After 
removal of the catalyst and solvent $1.98 \mathrm{~g}$ (4.73 mmol $97 \%$ ) of a mixture of compounds $4 \mathbf{a}$ and 5a $(2: 1)$ was obtained. The diastereoisomeric compounds were separated by crystallization from $\mathrm{MeOH} / \mathrm{THF} 1: 1$. Although 4a was generated in excess, 5a crystallized preferentially.

Characterization of $\mathbf{4 a}: \mathrm{R}_{\mathrm{f}}(\mathrm{CH}-$ EtOAc $1: 1)$ : 0,35; m.p. (MeOH): $159-161^{\circ} \mathrm{C}$; RI (trimethylsilylilated): 3050 (GC temperature program: $200{ }^{\circ} \mathrm{C} \quad 1 \mathrm{~min}, \quad 200-280{ }^{\circ} \mathrm{C} \quad 2 \mathrm{~K} / \mathrm{min}, \quad 280^{\circ} \mathrm{C}$ $15 \mathrm{~min}$ ); MS (trimethylsilylated) $\mathrm{m} / \mathrm{z}$ (rel. int.): 562 (M+ 84), 547 (5), 250 (7), 209 (100), 196 (18), 179 (17), 73 (21); ${ }^{1} \mathrm{H}-\mathrm{NMR}\left(500 \mathrm{MHz}, \mathrm{CDCl}_{3}\right): \delta$ (ppm) 2.9 (m 6H H-7 H-7' H-8), 3.62 (s 6H COOMe), 3.75 (s $6 \mathrm{H} \mathrm{ArOMe),} 5.48$ (s $1 \mathrm{H} \mathrm{OH}$ ), $6.44(\mathrm{~d} 1 \mathrm{H} J=2 \mathrm{~Hz} \mathrm{H}-6), 6.55(\mathrm{dd} 1 \mathrm{H} J=8 \mathrm{~Hz}$ $\left.J^{\prime}=2 \mathrm{~Hz} \mathrm{H}-6\right), 6.77(\mathrm{~d} 1 \mathrm{H} J=8 \mathrm{~Hz} \mathrm{H}-5) ;{ }^{13} \mathrm{C}-$ NMR (125 MHz CDCl $)$ ): $\delta$ (ppm) 35.3 (C-8), 47.6 (C-7), 51.8 (COOMe), 55.7 (Ar-OMe), 111.1 (C-2), 114.0 (C-5), 121.8 (C-6), 130.4 (C-1), 144.1 (C-4), 146.4 (C-3), 173.9 (C-9).

Characterization of 5a: $\mathrm{R}_{\mathrm{f}}(\mathrm{CH}-$ EtOAc $1: 1)$ : 0,34; m.p. (MeOH-THF 1:1): $198-199^{\circ} \mathrm{C}$; RI (trimethylsilylated): 3085 (GC temperature program: $200{ }^{\circ} \mathrm{C} 1 \mathrm{~min}, 200-280^{\circ} \mathrm{C} 2 \mathrm{~K} / \mathrm{min}, 280^{\circ} \mathrm{C}$ $15 \mathrm{~min})$; MS: no significant difference to $4 \mathbf{4 a} .{ }^{1} \mathrm{H}$ NMR (300 MHz): $\delta 2.75$ (m 4H H-7/7'), 2.99 (m $2 \mathrm{H} \mathrm{H}-8), 3.54$ (s $6 \mathrm{H}$ ArOMe), 3.83 (s 6H COOMe), 6.60 (m 4H H-2 H-4), 6.78 (d $2 \mathrm{H}^{3} J=$ $8 \mathrm{~Hz} \mathrm{H}-5)$.

\section{( \pm )-Secoisolariciresinol (6a)}

$\mathrm{LiAlH}_{4}$ reduction of $1.0 \mathrm{~g}(2.4 \mathrm{mmol})$ 4a in THF yielded $730 \mathrm{mg}(2.0 \mathrm{mmol} 84 \%)( \pm)$-secoisolariciresinol (6a).

$\mathrm{R}_{\mathrm{f}}\left(\right.$ EtOAc): 0.40; m.p. (EtOAc): $108^{\circ} \mathrm{C}$; RI (trimethylsilylated): $3050 ; \mathrm{MS} \mathrm{m} / \mathrm{z}$ (rel. int.): $362\left(\mathrm{M}^{+}\right.$ 12), 344 (4), 189 (6), 137 (100), 122 (9), 94 (5); ${ }^{1} \mathrm{H}$ NMR is in agreement with the literature (Agrawal and Rastogi, 1982).

\section{Meso-secoisolariciresinol (7a)}

A $\mathrm{LiAlH}_{4}$ reduction of $50 \mathrm{mg}(0.12 \mathrm{mmol}) \mathbf{4 a}$ in THF yielded $32 \mathrm{mg}(0.09 \mathrm{mmol}) 75 \%$ meso-secoisolariciresinol (7a).

$\mathrm{R}_{\mathrm{f}}$ (EtOAc): 0,35; m.p. (EtOAc) $110{ }^{\circ} \mathrm{C}$; RI (trimethylsilylated): 3050; MS (trimethylsilylated) $\mathrm{m} / \mathrm{z}$ (rel. int.): no significant difference to $6 \mathbf{6}$. ${ }^{1} \mathrm{H}$ -
NMR is in agreement with the literature (Agrawal and Rastogi, 1982).

\section{( \pm )-3,4-Divanillyltetrahydrofuran (8a)}

$100 \mathrm{mg}(0.28 \mathrm{mmol})$ of $( \pm)$-secoisolariciresinol were dissolved in $50 \mathrm{ml} \mathrm{MeOH}$. A mixture of $50 \mathrm{ml}$ trimethylorthoformate and $0.5 \mathrm{ml} \mathrm{H}_{2} \mathrm{SO}_{4}$ was added. The mixture was stirred at room temperature over night. After neutralization with $\mathrm{NaHCO}_{3}$ the solvent was reduced to $\sim 30 \mathrm{ml}$, diluted with $150 \mathrm{ml}$ diethylether and extracted with $2 \times 50 \mathrm{ml}$ brine. The organic phase was dried over $\mathrm{Na}_{2} \mathrm{SO}_{4}$. After removal of the solvent $92 \mathrm{mg}$ (0.27 mmol $95 \%)$ pure 3,4-divanillyltetrahydrofuran were obtained.

$\mathrm{R}_{\mathrm{f}} \quad(\mathrm{CH} /$ EtOAc 2:1): 0.38; m.p. (EtOAc): $121{ }^{\circ} \mathrm{C}$; RI (trimethylsilylated): 2920 ; MS $\mathrm{m} / z$ (rel/ int): 344 (M+24); 137 (100), 122(18), 94 (16); UV: $\varepsilon_{281}=6560 ;{ }^{1} \mathrm{H}-\mathrm{NMR}(500 \mathrm{MHz}): \delta(\mathrm{ppm}) 2.15$ $(\mathrm{m} 2 \mathrm{H} \mathrm{H}-8), 2.50\left(\mathrm{dd} 2 \mathrm{H}^{2} J=13.7 \mathrm{~Hz}^{3} \boldsymbol{J}=7.9 \mathrm{~Hz}\right.$ $\left.\mathrm{H}-7_{\mathrm{a}}\right), 2.56\left(\mathrm{dd} 2 \mathrm{H}^{2} J=13.7 \mathrm{~Hz}^{3} J=6.6 \mathrm{~Hz} \mathrm{H}-7_{\mathrm{b}}\right)$, $3.51\left(\mathrm{dd} 2 \mathrm{H}^{2} J=8.7 \mathrm{~Hz}^{3} J=5.7 \mathrm{~Hz} \mathrm{H}-9 \mathrm{a}\right), 3.81(\mathrm{~s}$ $6 \mathrm{H} \mathrm{ArOMe}), 3.89\left(\mathrm{dd} 2 \mathrm{H}^{2} J=8.7 \mathrm{~Hz}^{3} J=6.6 \mathrm{~Hz}\right.$ $\left.\mathrm{H}-9_{\mathrm{b}}\right), 6.48$ (d $\left.2 \mathrm{H}^{4} J=1.9 \mathrm{~Hz} \mathrm{H}-2\right), 6.57$ (dd $2 \mathrm{H}$ $\left.{ }^{3} J=8.0 \mathrm{~Hz}{ }^{4} J=8,0 \mathrm{~Hz}\right), 6.78\left(\mathrm{~d} 2 \mathrm{H}^{3} J=8.0 \mathrm{~Hz}\right)$. ${ }^{13} \mathrm{C}-\mathrm{NMR}$ (125 MHz): $\delta$ (ppm) 39.2 (C-8), 45.0 (C-7), 55.8 (ArOMe), 73.3 (C-9), 111.2 (C-2), 114.2 (C-5), 121.3 (C-6), 132.3 (C-4), 144.0 (C-1), 146.4 (C-3).

\section{Meso-3,4-divanillyltetrahydrofuran (9a)}

Analogous to 8a $12.3 \mathrm{mg}$ meso-3,4-divanillyltetrahydrofuran 9a were obtained by treatment of meso-secoisolariciresinol with trimethylorthoformate $/ \mathrm{H}_{2} \mathrm{SO}_{4}$.

$\mathrm{R}_{\mathrm{f}}\left(\mathrm{CH} /\right.$ EtOAc 2:1): 0.33; m.p.: $137^{\circ} \mathrm{C}$; RI (trimethylsilylated): 3050; MS (trimethylsilylated) $\mathrm{m} / \mathrm{z}$ (rel. int.): $488\left(\mathrm{M}^{+} 100\right), 473$ (8), 261 (5), 209 (56), 179 (18), 73 (13); ${ }^{1} \mathrm{H}-\mathrm{NMR}(500 \mathrm{MHz}$, $\left.\mathrm{CDCl}_{3}\right): \delta(\mathrm{ppm}) 2.48\left(\mathrm{~m} 2 \mathrm{H} \mathrm{H}-7_{\mathrm{a}}, 2.54 \mathrm{~m} 2 \mathrm{H} \mathrm{H}-\right.$ 8), $2.82(\mathrm{~m} 2 \mathrm{H} \mathrm{H}-7 \mathrm{~b}), 3.63\left(\mathrm{dd} 2 \mathrm{H}^{2} J=8.4 \mathrm{~Hz}^{3} J=\right.$ $5 \mathrm{~Hz} \mathrm{H}-9$ a), 3.78 (dd $2 \mathrm{H}^{2} J=8 \mathrm{~Hz}^{3} J=6 \mathrm{~Hz} \mathrm{H}-$ 9b), 3.84 (s $6 \mathrm{H} \mathrm{ArOMe),} 6.62\left(\mathrm{~d} 2 \mathrm{H}^{4} J=1.9 \mathrm{~Hz}\right.$ $\mathrm{H}-2), 6.66\left(\mathrm{dd}^{4} J=1.9 \mathrm{~Hz}^{3} J=8 \mathrm{~Hz} \mathrm{H}-6\right), 6.82(\mathrm{~d}$ $\left.2 \mathrm{H}^{3} \mathrm{~J}=8 \mathrm{~Hz} \mathrm{H}-5\right) ;{ }^{13} \mathrm{C}-\mathrm{NMR}\left(125 \mathrm{MHz} ; \mathrm{CDCl}_{3}\right)$ : $\delta$ (ppm) 33.0 (C-8), 43.8 (C-7), 55.8 (ArOMe), 72.9 (C-9), 111.2 (C-5), 114.3 (C-5), 121.2 (C-6), 132.5 (C-4), 143.8 (C-1), 146.4 (C-3). 
( \pm )-5,6-Di-(4-hydroxy-3-methoxy)-benzyl-

2,2-dimethyl-[1,3]dioxepane (12a)

$( \pm)$-Secoisolariciresinol $6 \mathbf{a}$ was treated with acetone $/ \mathrm{HClO}_{4}$ (Cambie et al., 1985). The byproduct 12a was separated by HPLC.

HPLC: solvent $\mathrm{CH}_{3} \mathrm{CN} / \mathrm{H}_{2} \mathrm{O}, 40 \% \mathrm{CH}_{3} \mathrm{CN}$ to $60 \% \mathrm{CH}_{3} \mathrm{CN}$ in $20 \mathrm{~min}, \mathrm{R}_{\mathrm{t}}=17.9 \mathrm{~min} ; \mathrm{R}_{\mathrm{f}}(\mathrm{CH} /$ EtOAc 2:1): 0.40; RI (trimethylsilylated): 3060 MS (trimethylsilylated) $\mathrm{m} / z$ (rel. int.): 402 (21), 344 (12), 194 (13), 180 (19), 150 (32), 137 (100), 122 (13); ${ }^{1} \mathrm{H}-\mathrm{NMR}\left(500 \mathrm{MHz}, \mathrm{CDCl}_{3}\right): 1.34$ (s $6 \mathrm{H}$ C-C $\left.\mathbf{H}_{3}\right), 1.56\left(\mathrm{~m} 2 \mathrm{H} \mathrm{H}-8 / 8^{\prime}\right), 2.58\left(\mathrm{dd} 2 \mathrm{H}^{2} J=13,9\right.$ $\left.\mathrm{Hz}^{3} J=6.8 \mathrm{~Hz} \mathrm{H}-7_{\mathrm{a}} / 7^{\prime}{ }_{\mathrm{a}}\right), 2.67\left(\mathrm{dd} 2 \mathrm{H}^{2} J=13.9 \mathrm{~Hz}\right.$ $\left.{ }^{3} J=7.5 \mathrm{~Hz} \mathrm{H}-7_{\mathrm{b}} / 7^{\prime}{ }_{\mathrm{b}}\right), 3.40\left(\mathrm{dd} 2 \mathrm{H}^{2} J=12.3 \mathrm{~Hz}\right.$ $\left.{ }^{3} J=5.2 \mathrm{~Hz} \mathrm{H}-9 \mathrm{a} / 9^{\prime}{ }_{\mathrm{a}}\right), 3.75$ (s $\left.3 \mathrm{H}\right), 3.83\left(\mathrm{dd} 2 \mathrm{H}^{2} J=\right.$ $\left.12.3 \mathrm{~Hz},{ }^{3} J=1,4 \mathrm{~Hz}^{3} J=5.2 \mathrm{~Hz} \mathrm{H}-9_{\mathrm{b}} / 9^{\prime}{ }_{\mathrm{b}}\right), 6.44(\mathrm{~d}$ $\left.{ }^{4} J=1.9 \mathrm{~Hz} \mathrm{H}-2\right), 6.54\left(\mathrm{dd}^{3} J=8.0 \mathrm{~Hz}{ }^{4} J=1.9 \mathrm{~Hz}\right.$ $\mathrm{H}-5), 6.76\left(\mathrm{~d}^{3} \mathrm{~J}=8.0 \mathrm{~Hz} \mathrm{H}-5\right) .{ }^{13} \mathrm{C}-\mathrm{NMR}(125$ $\left.\mathrm{MHz} ; \mathrm{CDCl}_{3}\right): 24.6\left(\mathrm{C}-\mathbf{C H}_{3}\right), 32,1(\mathrm{C}-8), 42.6$ (C-7), 55.6 (Ar-OMe), 61.2 (C-9), 111.2 (C-2), 113.2 (C-5), 121.2 C-6, 143.6 (C-1), 146.3 (C-3).

(-)-Matairesinol (10a) was obtained from Dr. R. Kasper (Pharmazeutische Biologie, Freie Universität Berlin).

\section{( \pm )-3-Vanillyltetrahydrofuran (11a)}

Hydrogenation of 1a (analogous 4a and 5a), reduction with $\mathrm{LiAlH}_{4}$ in THF and a dehydation with trimethylorthoformate $/ \mathrm{H}_{2} \mathrm{SO}_{4}$ yielded 11a.

RI (trimethylsilylated): $1850 ; \mathrm{MS} \mathrm{m} / \mathrm{z}$ (rel. int.): 208 ( $\mathrm{M}^{+}$64), 138 (57), 137 (100), 123 (9), 106 (8); ${ }^{1} \mathrm{H}-\mathrm{NMR}\left(300 \mathrm{MHz} \mathrm{CDCl}_{3}\right): \delta(\mathrm{ppm}) 1.58(\mathrm{~m} 1 \mathrm{H}$ $\mathrm{H}-8^{\prime}{ }_{\mathrm{a}}$ ), 1.97 (m $\left.1 \mathrm{H} \mathrm{H}-8{ }^{\prime}{ }_{\mathrm{b}}\right), 2.48$ (m $\left.1 \mathrm{H} \mathrm{H}-8\right), 2.61$ (d $2 \mathrm{H}^{3} J=8 \mathrm{~Hz} \mathrm{H}-7$ ), 3.4-4.0 (m 4H H-9/ H-9'), 3.83 (s $3 \mathrm{H} \mathrm{OMe}$ ), 6.64 (m 2H H-6/H-2), 6.81 (d $\left.1 \mathrm{H}^{3} J=8.5 \mathrm{~Hz} \mathrm{H}-5\right) ;{ }^{13} \mathrm{C}-\mathrm{NMR}\left(75 \mathrm{MHz}, \mathrm{CDCl}_{3}\right)$ : $\delta(\mathrm{ppm}) 32.04$ (C-8'), 38.92 (C-8), 41.14 (C-7), 55.79 (C-9'), 72.85 (C-9), 111.17 (C-2), 114.28 (C-5), 121.15 (C-6), 132.64 (C-1), 143.86 (C-4), $146.41(\mathrm{C}-3)$.

( \pm )-2,3-Bis-benzyldimethylsuccinate (4b) was obtained analogous to $\mathbf{4 a}$ using benzaldehyde instead of vanillin. After recrystallization from EtOAc the total yield of $( \pm)$-2,3-bis-benzyldimethylsuccinate $\mathbf{4 b}$ was $10.7 \%$.

RI: 2180; MS $m / z$ (rel. int.): $326\left(\mathrm{M}^{+} 4\right), 294$ (5), 264 (5), 175 (22), 131 (69), 104 (37), 91 (100). ${ }^{1} \mathrm{H}-$ NMR (300 MHz $\left.\mathrm{CDCl}_{3}\right): \delta(\mathrm{ppm}) 3.0(\mathrm{~m} 6 \mathrm{H} \mathrm{H}-7 /$ 8), 3.56 (s 6H COOMe), $7.05-7.30$ (10H m Ar).

\section{2,3 Bis(4-hydroxybenzyl)-butyrolactone (10c)}

2a was produced by Stobbe condensation of p-hydroxybenzaldehyde and dimethylsuccinate. Hydrogenation and reduction with $\mathrm{LiAlH}_{4}$ yielded a mixture of diastereoisomeres 10c.

Mixture of diasteroisomers 2:1 $( \pm)$ : meso; MS (rel. int.): 298 ( $\left.\mathrm{M}^{+} 23\right), 164$ (10), 134 (12), 108 (7), 107 (100), ${ }^{1} \mathrm{H}-\mathrm{NMR}\left(300 \mathrm{MHz}, \mathrm{D}_{4}\right.$-Methanol) ( \pm )10c: $\delta$ (ppm) $2.45-2.95$ (m $\left.6 \mathrm{H} \mathrm{H}-7 / 8 / 7^{\prime} / 8^{\prime}\right), 4.09$ (m $\left.2 \mathrm{H} \mathrm{H}-9^{\prime}\right), 6.72$ (d $\left.2 \mathrm{H} \mathrm{H}-2 / 6\right), 6.76$ (d $2 \mathrm{H} \mathrm{H}-2^{\prime} / 6^{\prime}$ ), $6.93(\mathrm{~d} 2 \mathrm{H} J=8.2 \mathrm{~Hz} \mathrm{H}-3 / 5), 7,02(\mathrm{~d} 2 \mathrm{H} J=8.2 \mathrm{~Hz}$ H-3'/5'). Meso-10c: $\delta$ (ppm) 3.25-2.45 (m 6H H-7/ $\left.8 / 7^{\prime} / 8^{\prime}\right), 3.92\left(\mathrm{~m} 2 \mathrm{H} \mathrm{H} 9 / 9^{\prime}\right), 6.69\left(2 \mathrm{H} \mathrm{d}^{3} \mathrm{~J}=8.2 \mathrm{~Hz}\right.$ $\mathrm{H}-2 / 6), 6.80\left(2 \mathrm{H} \mathrm{d}^{3} J=8.2 \mathrm{~Hz} \mathrm{H}-2^{\prime} / 6^{\prime}\right), 6.91(2 \mathrm{H} \mathrm{d}$ $\left.{ }^{3} J=8.2 \mathrm{~Hz} \mathrm{H}-3 / 5\right), 7.20\left(\mathrm{~d} 2 \mathrm{H}^{3} J=8.2 \mathrm{~Hz} \mathrm{H}-3^{\prime} / 5^{\prime}\right)$.

2-(4-Hydroxy-3-methoxy-benzyl)-3-benzyldimethylsuccinate (4d) was synthesized as described for $\mathbf{4 a}$ using benzaldehyde, dimethylsuccinate and vanillin.

HPLC $50 \%$ aqueous MeCN isocratic $\mathrm{R}_{\mathrm{t}}=$ $16.1 \mathrm{~min}$; RI (trimethylsilylated): 2650; MS (rel. int.): 373 (19), 372 (M+ 85), 341 (10), 309 (9), 221 (14), 209 (52), 208 (23), 178 (10), 177 (54), 137 (100), 124 (15), 91 (8); ${ }^{1} \mathrm{H}-\mathrm{NMR}$ (500 MHz, $\left.\mathrm{CDCl}_{3}\right): \delta$ (ppm) 2.85-3.05 (m 6H H-7/8), 3.60 (s 3H COOMe), 3.62 (s 3H COOMe), 3.79 (s $3 \mathrm{H}$ ArOMe), 5.5 (s $1 \mathrm{H}$ ArOH), 6.52 (d $J=2 \mathrm{~Hz}$ $\mathrm{H}-2$ ), 6.58 (dd $\left.1 \mathrm{H} J=8 \mathrm{~Hz} J^{\prime}=2 \mathrm{~Hz} \mathrm{H}-6\right), 6.80$ (d $1 \mathrm{H} J=8 \mathrm{~Hz} \mathrm{H}-5), 7.07$ (m $\left.2 \mathrm{H} \mathrm{H}-2^{\prime} / 6^{\prime}\right), 7.2$ (m $1 \mathrm{H}$ $\left.\mathrm{H}-4^{\prime}\right), 7.25$ (m $\left.2 \mathrm{H} \mathrm{H}-3^{\prime} / 5^{\prime}\right)$.

2-(4-Hydroxy-3-methoxy-benzyl)-3-benzyldimethylsuccinate (5d) was synthesized analogous to 5a using benzaldehyde, dimethylsuccinate and vanillin.

HPLC: solvent $\quad \mathrm{CH}_{3} \mathrm{CN} / \mathrm{H}_{2} \mathrm{O}, \quad 50 \% \quad \mathrm{CH}_{3} \mathrm{CN}$ isocratic, $\mathrm{R}_{\mathrm{t}}=13.2 \mathrm{~min}$; $\mathrm{RI}$ (trimethylsilylated): 2650; MS: no significant difference to $4 \mathbf{d}$; ${ }^{1} \mathrm{H}-\mathrm{NMR}$ (500 MHz, CDCl3): $\delta(\mathrm{ppm}) 2.69-2.91(\mathrm{~m} 4 \mathrm{H} \mathrm{H}-$ $\left.7 / 7^{\prime}\right), 3.2$ (m $\left.2 \mathrm{H} \mathrm{H}-8 / 8^{\prime}\right), 3.52$ (s 3H COOMe), 3.53 (s 3H H-COOMe), 3.83 (s 3H H-OMe), 5.48 (s $1 \mathrm{H}$ $\mathrm{OH}), 6.59$ (m 2H H-2/6), 6.78 (d $1 \mathrm{H} J=8.4 \mathrm{~Hz} \mathrm{H}-$ 5), 7.11 (m $\left.2 \mathrm{H} \mathrm{H}-2^{\prime} / \mathrm{H}^{\prime}\right), 7.18$ (m $\left.1 \mathrm{H} \mathrm{H}^{\prime} 4^{\prime}\right), 7.24$ (m $\left.2 \mathrm{H}-3^{\prime} / 5^{\prime}\right)$

2-(4-Hydroxy-3,5-dimethoxy-benzyl)-3-benzyldimethylsuccinate (4e) was synthesized analogous to $4 \mathbf{a}$ using benzaldehyde, dimethylsuccinate and syringaldehyde.

HPLC: solvent $\mathrm{MeOH} / \mathrm{H}_{2} 0,60 \% \mathrm{MeOH}$ isocratic, $\mathrm{R}_{\mathrm{t}}=14.8 \mathrm{~min} ; \mathrm{RI}$ (trimethylsilylated): 2795 ; 
MS (rel. int.): 402 (78), 371 (6), 239 (37), 238 (19), 207 (42), 167 (100), 91 (8); ${ }^{1} \mathrm{H}-\mathrm{NMR}(500 \mathrm{MHz}$ $\left.\mathrm{CDCl}_{3}\right) \delta(\mathrm{ppm}) 2.84-3.06\left(\mathrm{~m} 6 \mathrm{H} \mathrm{H}-7 / 7^{\prime} / 8 / 8^{\prime}\right), 3.60$ (s 3H COOMe), 3.61 (s 3H COOMe), 3.78 (s 6H ArMe $)$, 7.04-7.24 (m 5H H-Ar); ${ }^{13} \mathrm{C}-\mathrm{NMR}$ $\left(125 \mathrm{MHz} \mathrm{CDCl}_{3}\right) \delta$ (ppm) 35.52, 35.77, 47.65, 48.02, 51.74, 51.76, 56.20, 105.58, 126.50, 128.40, 128.99, $129.56,133.30,138.55,146.88,173.75,173.81$.

2-(4-Hydroxy-3,5-dimethoxy-benzyl)-3-benzyldimethylsuccinate (5e) was synthesized analogous to 5a using benzaldehyde, dimethylsuccinate and vanillin.

HPLC: solvent $\mathrm{MeOH} / \mathrm{H}_{2} 0,60 \% \mathrm{MeOH}$ isocratic, $\mathrm{R}_{\mathrm{t}}=12.6 \mathrm{~min}$; $\mathrm{RI}$ (trimethylsilylated): 2795 ; MS no significant difference to $\mathbf{4 e} ;{ }^{1} \mathrm{H}-\mathrm{NMR}$ (500 $\mathrm{MHz} \mathrm{CDCl}_{3}$ ): $\delta$ (ppm) 2.69-3.07 (m 6H H-7/7'/8/ $8^{\prime}$ ), 3.53 (3H s $3 \mathrm{H}$ COOMe), 3.56 (s 3H COOMe), 3.82 (s $6 \mathrm{H} \mathrm{ArOMe}$ ), 7.1-7.3 (m 7H Ar-H); ${ }^{13} \mathrm{C}-$ NMR (125 MHz $\mathrm{CDCl}_{3}$ ): $\delta$ (ppm) 36.57, 36.69, 49.80, 50.16, 51.66, 51.70, 56.24, 105.38, 126.62, $128.43,128.79,129.13,133.29,138.22,146.85$, 173.88 .

Derivatisation of ( \pm )-3,4-divanillyltetrahydrofuran with diazomethane

( \pm )-3,4-divanillyltetrahydrofuran was treated with $\mathrm{CH}_{2} \mathrm{~N}_{2}$ in diethylether yielding a mixture of different methylated products which were separated by HPLC.

\section{(士)-3,4-Bis-(3,4-dimethoxybenzyl)-tetrahydro-} furan $(\mathbf{8 g})$

HPLC: solvent $\mathrm{CH}_{3} \mathrm{CN} / \mathrm{H}_{2} \mathrm{O}, 40 \% \mathrm{CH}_{3} \mathrm{CN}$ to $60 \% \mathrm{CH}_{3} \mathrm{CN}$ in $20 \mathrm{~min}, \mathrm{R}_{\mathrm{t}}=16.4 \mathrm{~min}$; RI: 2800;

Adlercreutz H., Fotsis T., Watanabe S., Lampe J., Wahala K., Makela T. and Hase T. (1994), Determination of lignans and isoflavonoids in plasma by isotope dilution gas chromatography-mass spectrometry. Cancer Detect. Prev. 18, 259-71.

Agrawal P. K. and Rastogi R. P. (1982), Two lignans from Cedrus deodara. Phytochemistry 21, 1459-61.

Batterbee J. E., Burden R. S., Crombie L. and Whiting D. A. (1969), Chemistry and synthesis of the lignan (1)-cubebin. J. Chem. Soc. C 18, 2470-7.

Cambie R. C., Clark G. R., Craw P. A. and Jones T. C., Rutledge P. S. and Woodgate P. D. (1985), Chemistry of the Podocarpaceae. LXIX. Further lignans from the wood of Dacrydium intermedium. Aust. J. Chem. 38, $1631-45$.
MS (rel. int.): $372\left(\mathrm{M}^{+} 30\right), 152$ (97), 137 (20), 121 (24), 107 (14), 91 (9). ${ }^{1} \mathrm{H}-\mathrm{NMR}\left(300 \mathrm{MHz}, \mathrm{CDCl}_{3}\right)$ : $2.18(\mathrm{~m} 2 \mathrm{H} \mathrm{H}-8), 2.52\left(\mathrm{dd} 2 \mathrm{H}^{2} J=13.8 \mathrm{~Hz}^{3} J=8.2\right.$ $\left.\mathrm{Hz} \mathrm{H}-7_{\mathrm{a}}\right), 2.63\left(\mathrm{dd} 2 \mathrm{H}^{2} J=13.8 \mathrm{~Hz}{ }^{3} J=6.2 \mathrm{~Hz}\right.$ $\left.\mathrm{H}-7_{\mathrm{b}}\right), 3.52\left(\mathrm{dd} 2 \mathrm{H}^{2} J=8.7 \mathrm{~Hz}^{3} J=6.0 \mathrm{~Hz} \mathrm{H}-9_{\mathrm{a}}\right)$, 3.83 (s 6H OMe), 3.85 (s $6 \mathrm{H}$ OMe), 3,90 (dd 2H $\left.{ }^{2} J=8.7 \mathrm{~Hz}^{3} J=6,6 \mathrm{~Hz} \mathrm{H}-9 \mathrm{~b}\right), 6.6 \mathrm{O}\left(\mathrm{d} 2-\mathrm{H}^{4} J=2.0\right.$ $\mathrm{Hz} \mathrm{H}-2), 6.62\left(\mathrm{dd} 2 \mathrm{H}^{3} J=8.1 \mathrm{~Hz}{ }^{4} J=2.0 \mathrm{~Hz}\right.$ $\mathrm{H}-6), 6.75$ (d $\left.2 \mathrm{H}^{3} J=8.1 \mathrm{~Hz} \mathrm{H}-5\right)$.

3-(3,4-Dimethoxybenzyl)-4-(4-hydroxy-3-methoxybenzyl)-tetrahydrofuran (8f)

HPLC: solvent $\mathrm{CH}_{3} \mathrm{CN} / \mathrm{H}_{2} \mathrm{O}, 40 \% \mathrm{CH}_{3} \mathrm{CN}$ to $60 \% \mathrm{CH}_{3} \mathrm{CN}$ in $20 \mathrm{~min}$, RI (trimethylsilylated): 2860; $\mathrm{R}_{\mathrm{t}}=12.4 \mathrm{~min} ; \mathrm{MS}$ (rel. int.): $358\left(\mathrm{M}^{+} 26\right)$, 152 (77), 151 (100), 138 (27), 137 (82); ${ }^{1} \mathrm{H}-\mathrm{NMR}$ $\left(300 \mathrm{MHz}, \mathrm{CDCl}_{3}\right): 2.17$ (m $\left.2 \mathrm{H} \mathrm{H}-7\right), 2.46-2.62$ (m 4H H-7), 3.51 (m 2H H-9a), 3.81 (s 3H OMe), 3.82 (s $3 \mathrm{H} \mathrm{OMe}$ ), 3.84 (s $3 \mathrm{H}$ OMe), 3.9 (m 2H $\mathrm{H}-9 \mathrm{~b}$ ), 6.50-6.64 (m 4H H-2/6), 6.74 (d 1H $J=$ $8 \mathrm{~Hz} \mathrm{H}-5), 6.80$ (d $\left.1 \mathrm{H} J=8 \mathrm{~Hz} \mathrm{H}-5^{\prime}\right)$.

\section{Acknowledgements}

We thank Mr. K. Pöllmann and Dr. J. Reiner for NMR-Data and Dr. R. Kasper of the Department of Pharmazeutische Biologie, Freie Universität Berlin, Germany, for the generous gift of (-)-matairesinol. Furthermore we are very grateful to Kanoldt Arzneimittel $\mathrm{GmbH}$ for the financial support.
Coran S. A., Bambagiotti-Alberti M., Melani F., Giannellini V., Vincieri F. F., Mulinacci N. and Sala R. (1991), Synthetic butanolide and tetrahydrofuran lignans with platelet activating factor antagonist activity. Eur. J. Med. Chem. 26, 643-50.

Cunningham G. R., Tindall D. J., Lobl T. J., Campbell J. A. and Means A. R. (1981), Steroid structural requirements for high affinity binding to human sex steroid binding protein (SBP). Steroids 38, 243-62.

Daugan A. and Brown E. (1991), Lignans. 11. Preparation of $(\mathrm{R})-(+)-\beta$-vanillyl- $\gamma$-butyrolactone and its use in the total synthesis of natural lignans. J. Nat. Prod. 54, 110-18.

Dunn J. F., Merriam G. R., Eil C., Kono S., Loriaux D. L. and Nisula B. C. (1980), Testosterone-estradiol bind- 
ing globulin binds to 2-methoxyestradiol with greater affinity than to testosterone. J. Clin. Endocrinol. Metab. 51, 404-6.

Farnsworth W. E. (1996), Roles of estrogen and SHBG in prostate physiology. Prostate (N. Y.) 28, 17-23.

Ganßer D. and Spiteller G. (1995) Plant constituents interfering with human sex hormone-binding globulin. Evaluation of a test method and its application to Urtica dioica root extracts Z. Naturforsch. 50 c, 98-104.

Hammond G. L. and Bocchinfuso W. P. (1995), Sex hormone-binding globulin/androgen-binding protein: steroid-binding and dimerization domains. J. Steroid Biochem. Mol. Biol. 53, 543-5.

Hirano T., Oka K., Naitoh T. and Hosaka K. (1989), Endogenous digoxin-like activity of mammalian-lignans and their derivatives. Res. Commun. Chem. Pathol. Pharmacol. 64, 227-40.

Hirano T., Fukuoka K., Oka K., Naito T., Hosaka K., Mitsuhashi H. and Matsumoto Y. (1990), Antiproliferative activity of mammalian lignan derivatives against the human breast carcinoma cell line, ZR-75-1. Cancer Invest. 8, 595-602.

Hryb D. J., Khan M. S., Romas N. A. and Rosner W. (1990). The control of the interaction of sex hormonebinding globulin with its receptor by steroid hormones. J. Biol. Chem. 265, 6048-54.

Joseph D. R. (1994), Structure, function, and regulation of androgen-binding protein/sex hormone-binding globulin. Vitam. Horm. (San Diego), 49 (Steroids), 197-280.

Kalinowski H. (1987), Carbon 13 NMR Spectroscopy. John Wiley \& Sons Inc., New York, N. Y., 730 pp.

Martin M. E., Haourigui M., Pelissero C., Benassayag C. and Nunez E. A. (1995), Interactions between phytoestrogens and human sex steroid binding protein. Life Sci. 58, 429-36.

Matsuura S., and Iinuma M. (1985), Lignan from calyces of Diospyros kaki. Phytochemistry 24, 626-8.
MacRae W. D. and Towers G. H. N. (1984), Biological activities of lignans. Phytochemistry 23, 1207-20.

Mendel C. M. (1989), The free hormone hypothesis: a physiologically based mathematical model. Endocr. Rev. 10, 232-74.

Nishibe S. (1993), Lignans as bioactive components in traditional medicines. Polyphenolic Phenom., 247-55. Ed.: Scalbert, A. Publ.: INRA, Paris, Fr..

Pugeat M., Garrel D., Estour B., Lejeune H., Kurzer M. S., Tourniaire J. and Forest M. G. (1988), Sex steroid-binding protein in nonendocrine diseases. Ann. N. Y. Acad. Sci. 538 (Steroid-Protein Interact.: Basic Clin. Aspects), 235-47.

Schöttner M., Ganßer D. and Spiteller G. (1997), Lignans from the roots of Urtica dioica and their metabolites bind to sex hormone binding globulin (SHBG). Planta Med. 63, in press..

Setchell K. D. R., Lawson A. M., Mitchell F. L., Adlercreutz H., Kirk D. N. and Axelson M. (1980), Lignans in man and in animal species. Nature 287, 740-2.

Setchell K. D. R. and Adlercreutz, H. (1988), Mammalian lignans and phytoestrogens. Recent studies on their formation, metabolism and biological role in health and disease. In: Role of the Gut Flora in Toxicity and Cancer (Rowland, I. R., ed.), Publ.: Acad. Press Ltd.

Stitch S. R., Toumba J. K., Groen M. B., Funke C. W., Leemhuis J., Vink J. and Woods G. F. (1980), Excretion, isolation and structure of a new phenolic constituent of female urine. Nature 287, 738-40.

Van den Dool H. and Kratz P. D. (1963), A generalization of the retention index system including linear temperature programmed gas-liquid partition chromatography. J. Chrom. 11, 463-71.

Vermeulen A., Stoica T. and Verdonck L. (1971), Apparent free testosterone concentration, an index of androgenicity. J. Clin. Endocrinol. Metab. 33, 759-67.

Ward R. S. (1982), The synthesis of lignans and neolignans. Chem. Soc. Rev. 11, 75-125. 